\title{
Total Bakteri dan Fungi serta Kandungan Nutrisi dari Ampas Kelapa yang Diberi Ekstrak Daun Kersen dengan Lama Penyimpanan Berbeda
}

\author{
Total Bacteria and Fungi as well as Nutrient Content of Coconut Pulp Added with Cherry \\ Leaf Extract in Different Storage Periods
}

\section{A. E. Karina, R. I. Pujaningsih dan T. Yudiarti}

Fakultas Peternakan dan Pertanian, Universitas Diponegoro

Corresponding Author : eryekarina@gmail.com

\begin{abstract}
This study aimed to determine and evaluate the effect of added cherry leaf extract on coconut pulp on total bacteria and fungi along with nutrient content in different storage periods. Cherry leaf extract was extracted using soxhletation method. The concentration of cherry leaf extract used was $50 \%$. Coconut pulp was given two treatments, T0 was not added with cherry leaf extract and T1 was added with cherry leaf extract with a ratio of 10: $1(\mathrm{w} / \mathrm{v})$ given treatment storage duration of each M0 (week 0 storage time), M2 (week 2 storage time) and M4 (week 4 storage time). The design used was Completely Randomized Design (CRD) factorial pattern with 2 factor treatments and 3 replications. The parameters observed were total fungi, total bacteria, and nutrient content. The treatments of added cherry leaf extract was significantly different $(\mathrm{p}<0.05)$ on total of fungi, total bacteria, crude fat content, and crude protein content. The treatment of storage time was significantly different $(\mathrm{P}$ $<0.05$ ) on water content, ash content and crude fiber of coconut pulp. Cherry leaf extract added to coconut pulp can reduce the total number of fungi but can not decrease on the number of total bacteria nor do preserve nutrient content of coconut pulp during storage.
\end{abstract}

Key words: coconut pulp, cherry leaf extract, total fungi, total bacteria, nutrient content.

\begin{abstract}
ABSTRAK
Penelitian ini bertujuan untuk mengetahui dan mengevaluasi pengaruh dari pemberian ekstrak daun kersen pada ampas kelapa terhadap total bakteri, total fungi serta kandungan nutrisi pada lama penyimpanan yang berbeda. Ekstrak daun kersen diekstraksi menggunakan metode sokletasi. Konsentrasi ekstrak daun kersen yang digunakan adalah 50\%. Ampas kelapa diberi 2 perlakuan yaitu $\mathrm{T}_{0}$ tidak ditambah ekstrak daun kersen dan $\mathrm{T}_{1}$ ditambah ekstrak daun kersen dengan perbandingan $1: 10(\mathrm{v} / \mathrm{w})$ serta diberi perlakuan lama penyimpanan masing-masing $\mathbf{M}_{0}$ (lama penyimpanan minggu ke -0), $\mathbf{M}_{2}$ (lama penyimpanan minggu ke-2) dan $\mathbf{M}_{4}$ (lama penyimpanan minggu ke - 4). Rancangan yang digunakan adalah Rancangan Acak Lengkap (RAL) pola faktorial dengan 2 faktor perlakuan dan 3 ulangan. Parameter yang diamati adalah total bakteri, total fungi dan kandungan nutrisi. Perlakuan pemberian ekstrak daun kersen berbeda nyata $(\mathrm{P}<0,05)$ terhadap total fungi, total bakteri, kadar lemak kasar, dan kadar protein kasar. Sedangkan lama penyimpanan berbeda nyata $(\mathrm{P}<0,05)$ terhadap kadar air, kadar abu dan serat kasar ampas kelapa. Ekstrak daun kersen yang ditambahkan pada ampas kelapa mampu mengurangi pertumbuhan fungi, namun tidak dapat mengurangi pertumbuhan bakteri serta tidak dapat mempertahankan kandungan nutrisi ampas kelapa selama penyimpanan.
\end{abstract}

Kata kunci: Ampas kelapa, ekstrak daun kersen, total fungi, total bakteri, kandungan nutrisi.

\section{PENDAHULUAN}

Ampas kelapa merupakan limbah hasil samping dari pembuatan santan. Limbah pertanian ini tersedia dalam jumlah banyak dan belum dimanfaatkan secara optimal (Hidayati, 2011). Ampas kelapa dapat digunakan sebagai bahan pakan untuk ternak unggas terutama ayam (Yamin, 2008). Pemanfaatan ampas kelapa untuk pakan dapat menggantikan sebagian penggunaan bahan pakan yang harganya tinggi, sehingga dapat mengurangi biaya produksi sekaligus meningkatkan keuntungan (Farizaldi, 2016). Kandungan nutrien yang terdapat dalam ampas kelapa yaitu protein 5,78\%; lemak $38,24 \%$ dan serat kasar 15,07\% (Putri, 2010) dan zat anti nutrisi yaitu $61 \%$ galaktomanan, $26 \%$ manan, dan $16 \%$ selulosa (Pravitasari, 2017). 
Cara pemberian ampas kelapa secara langsung ke ternak dosisnya harus dibatasi, hal ini karena kandungan lemaknya yang masih tinggi. Kandungan lemak yang tinggi pada pakan menyebabkan adanya proses oksidasi sehingga menimbulkan ketengikan. Ketengikan disebabkan karena adanya peroksidan yang mampu untuk mempercepat proses oksidasi, sehingga diperlukan sumber aditif yaitu antioksidan yang dapat mengurangi kecepatan proses oksidasi (Retnani et al., 2010). Terdapat beberapa katalik sistem yang dapat mengoksidasi lemak salah satunya adalah mikroorganisme (Retnani et al., 2010). Kelebihan ampas kelapa yang belum termanfaatkan biasanya akan mudah membusuk, dikarenakan adanya mikroba patogen. Ampas kelapa yang tidak melalui proses pengeringan tidak akan tahan lama jika disimpan dan akan memudahkan tumbuhnya mikroba untuk berkembang. Salah satu upaya untuk menghambat pertumbuhan mikroba yaitu dengan diberikan ekstrak daun kersen.

Kersen (Muntingia calaburaL.) adalah sejenis pohon yang memiliki buah yang kecil dan manis. Tanaman kersen merupakan tanaman asli dari benua Amerika, namun telah tersebar di wilayah Asia. Bagianbagian tanaman kersen yaitu batang, buah dan daunnya digunakan sebagai obat tradisional. Daun kersen merupakan tumbuhan yang banyak dan mudah untuk dicari. Daun kersen merupakan jenis daun yang memiliki senyawa aktif berupa flavonoid, tanin dan saponin, sehingga daun kersen dapat digunakan sebagai antioksidan atau antimikroba. Penelitian ini bertujuan untuk mengetahui dan mengevaluasi pengaruh dari pemberian ekstrak daun kersen pada ampas kelapa terhadap kandungan total bakteri, total fungi serta kandungan nutrisi pada lama penyimpanan yang berbeda. Penelitian ini bermanfaat untuk memperoleh informasi pengaruh penambahan ekstrak daun kersen terhadap kandungan total bakteri, total fungi dan lama penyimpanan pada ampas kelapa dan mengetahui fungsi daun kersen sebagai antibakteri.

\section{MATERI DAN METODE}

Penelitian ini dilaksanakan selama dua bulan di Laboratorium Teknologi Pakan, Fakultas Peternakan dan Pertanian Universitas Diponegoro Semarang. Analisis Mikrobiologi di Laboratorium Analisis Kesehatan SMK Theresiana, Semarang, dan Analisis Proksimat di Laboratorium Ilmu Nutrisi dan Pakan Fakultas Peternakan dan Pertanian, Universitas Diponegoro, Semarang.

Materi yang digunakan dalam penelitian ini yaitu alat yang terdiri dari nampan, alumunium foil, oven, blender, saringan, timbangan analitik, cawan petri, mikroskop, pipet, kertas saring, karung blacu, tabung reaksi, saringan, tisu dan loyang kecil. Bahan terdiri atas ampas kelapa, ekstrak daun kersen, etanol 97\%, dan $\mathrm{NaCl} 0,85 \%$. Metode yang digunakan dalam penelitian ini meliputi tahap persiapan, pelaksanaan penelitian dan tahap analisis.

\section{Rancangan Penelitian}

Penelitian ini menggunakan Rancangan Acak Lengkap (RAL) dengan 2 faktor perlakuan 3 ulangan, perlakuan yang dilakukan sebagai berikut :

Faktor A

T0 : Tidak diberi ekstrak daun kersen

T1 : Pemberian ekstak daun kersen

\section{Faktor B}

M0 : Penyimpanan minggu ke-0

M2 : Penyimpanan minggu ke-2

M4 : Penyimpanan minggu ke-4

Prosedur penelitian ini meliputi tahap persiapan, tahap perlakuan dan tahap analisis.

\section{Tahap Persiapan}

Pembuatan serbuk daun kersen yaitu dengan pengumpulan daun kersen yang tua dan dilakukan pencucian daun kersen pada air yang mengalir. Daun yang telah dicuci diangin-anginkan selama 24 jam, kemudian pengeringan dengan oven bersuhu $60{ }^{\circ} \mathrm{C}$ selama 24 jam serta penggilingan daun kersen menggunakan blender lalu dilakukan penyaringan. Pembuatan ekstrak daun kersen menggunkan metode ekstraksi sokletasi. 


\section{Tahap Perlakuan}

Ampas kelapa dicampur dengan hasil ekstraksi (sokletasi) daun kersen konsentrasi 50\% (1 : 1, ekstrak daun kersen : etanol 97\%) dengan pencampuran ekstrak $100 \mathrm{ml}$ per $1000 \mathrm{~g}$ berat ampas kelapa dengan perbandingan 1 : 10. Pengamatan dilakukan pada minggu ke-0, ke-2 dan ke-4 pada penyimpanan suhu ruang dan dikemas dengan karung blacu.

\section{Tahap Analisis}

Analisis total fungi dan total bakteri dilakukan di Laboratorium Analisis Kesehatan SMK Theresiana, Semarang, dan analisis proksimat kandungan nutrisi dilakukan di Laboratorium Ilmu Nutrisi dan
Pakan Fakultas Peternakan dan Pertanian, Universitas Diponegoro, Semarang.

\section{HASIL DAN PEMBAHASAN}

\section{Kandungan Nutrisi}

Berdasarkan hasil penelitian pada Tabel 1 menunjukkan bahwa terdapat pengaruh nyata $(\mathrm{P}<0,05)$ pada perlakuan lama penyimpanan yang berbeda terhadap kadar air, kadar abu, dan kadar serat kasar ampas kelapa. Perlakuan pemberian ekstrak daun kersen berbeda nyata $(\mathrm{P}<0,05)$ terhadap kadar lemak kasar, dan kadar protein kasar ampas kelapa.

Tabel 1. Rata-rata kandungan nutris ampas kelapa yang diberi perlakuan selama penyimpanan

\begin{tabular}{|c|c|c|c|c|}
\hline \multirow{2}{*}{ Bahan } & \multirow{2}{*}{ Perlakuan } & \multicolumn{3}{|c|}{ Lama Penyimpanan (\%) } \\
\hline & & M0 & M2 & M4 \\
\hline \multirow{2}{*}{ Kadar Air } & T0 & $14,5^{\mathrm{a}}$ & $12,06^{b}$ & $11,81^{b}$ \\
\hline & $\mathrm{T} 1$ & $14,3^{\mathrm{a}}$ & $11,29^{b}$ & $11,12^{b}$ \\
\hline \multirow{2}{*}{ Kadar Abu } & T0 & $4,90^{\mathrm{a}}$ & $5,10^{\mathrm{b}}$ & $5,57^{\mathrm{c}}$ \\
\hline & $\mathrm{T} 1$ & $4,10^{\mathrm{a}}$ & $4,93^{b}$ & $4,87^{\mathrm{c}}$ \\
\hline \multirow{2}{*}{ Lemak Kasar } & T0 & $26,5^{\mathrm{e}}$ & $29,8^{\mathrm{c}}$ & $29,63^{\mathrm{d}}$ \\
\hline & $\mathrm{T} 1$ & $29,1^{\mathrm{d}}$ & $31,0^{b}$ & $31,94^{\mathrm{a}}$ \\
\hline \multirow{2}{*}{ Serat Kasar } & T0 & $48,4^{\mathrm{a}}$ & $48,0^{\mathrm{b}}$ & $47,53^{\mathrm{bc}}$ \\
\hline & $\mathrm{T} 1$ & $46,8^{\mathrm{de}}$ & $47,9^{\mathrm{bc}}$ & $47,12^{\mathrm{cd}}$ \\
\hline \multirow{2}{*}{ Protein Kasar } & T0 & $4,81^{\mathrm{d}}$ & $5,50^{\mathrm{b}}$ & $5,71^{\mathrm{a}}$ \\
\hline & $\mathrm{T} 1$ & $4,95^{\mathrm{d}}$ & $5,46^{\mathrm{bc}}$ & $5,01^{\mathrm{c}}$ \\
\hline
\end{tabular}

Keterangan : Superskrip yang berbeda pada baris dan kolom yang sama menunjukkan perbedaan nyata $(\mathrm{P}<0,05)$

Berdasarkan hasil uji proksimat yang dilakukan, menunjukkan adanya pengaruh nyata $(p<0,05)$ pada perlakuan lama penyimpanan yang berbeda terhadap kadar air ampas kelapa. Hal ini menunjukkan bahwa perlakuan lama penyimpanan menurunkan kadar air dari ampas kelapa. Kadar air tertinggi yaitu $14,56 \%$ (T0M0), sedangkan angka penurunan kadar air terendah yaitu $11,12 \%$ (T1M4). Uji wilayah berjarak Duncan terhadap kandungan kadar air ampas kelapa tersaji pada tabel 1 .

Penurunan kadar air pada ampas kelapa dikarenakan lama penyimpanan. Hal ini sesuai dengan pendapat Solihin et al. (2015) menyatakan bahwa penurunan kadar air selama masa simpan dapat terjadi karena proses evaporasi dari bahan pakan ke lingkungan sekitar. Purwanti et al. (2017) juga menyatakan bahwa penurunan kadar air disebabkan karena terjadinya penguapan air dari bahan pakan ke permukaan. Retnani et al. (2010) menjelaskan bahwa lama penyimpanan sangat berpengaruh terhadap kadar air. Penurunan kadar air yang terjadi memungkinkan ampas kelapa dapat disimpan dalam waktu yang lama. Hal ini sesuai dengan pendapat Sari et al. (2016) menyatakan bahwa kandungan kadar air yang rendah pada suatu bahan dapat meningkatkan daya simpan, kemungkinan kerusakan bahan pakan akan lebih sedikit.

Hasil dari uji proksimat menunjukkan pengaruh nyata $(p<0,05)$ pada perlakuan 
lama penyimpanan yang berbeda terhadap kadar abu ampas kelapa. Kadar abu yang dihasilkan tertinggi yaitu 5,57\% (T0M4) dan terendah yaitu $4,10 \%$ (T1M0). Uji wilayah berjarak Duncan terhadap kadar abu ampas kelapa tersaji pada tabel 1 .

Kadar abu mengalami peningkatan pada perlakuan lama penyimpanan baik pada ampas kelapa tanpa penambahan ekstrak daun kersen maupun dengan penambahan ekstrak daun kersen. Peningkatan kadar abu dapat terjadi karena bertambahnya kandungan mineral yang terdapat pada ampas kelapa. Menurut Wulandari et al. (2015) semakin tinggi kadar abu yang dihasilkan maka semakin tinggi pula kadar mineralnya. Widaningrum et al. (2010) menyatakan bahwa kadar abu menunjukkan besarnya kandungan mineral yang ada dalam bahan pakan yang disimpan, karena mineral merupakan suatu zat anorganik yang tidak terbakar selama proses pembakaran. Ampas kelapa yang disimpan dalam waktu yang lama akan menunjang tumbuhnya mikroba, dalam tubuh mikroba terkandung mineralmineral untuk penyusunan tubuhnya. Hal ini sesuai dengan pendapat Puspitasari dan Sidik (2009) menyatakan bahwa mikroorganisme memerlukan mineral tertentu untuk pertumbuhan dan metabolisme. Menurut Farizaldi (2016) semakin lama penyimpanan ampas kelapa maka mikroorganisme semakin banyak. Malaka et al. (2013) menyatakan bahwa mikroba membutuhkan beberapa jenis mineral untuk mendukung pertumbuhannya.

Berdasarkan hasil uji proksimat pada ampas kelapa, menunjukkan adanya pengaruh nyata $(\mathrm{p}<0,05)$ pada perlakuan pemberian ekstrak daun kersen dan lama penyimpanan yang berbeda terhadap kadar lemak kasar. Kandungan lemak kasar tertinggi yaitu 31,94\% (T1M4) dan terendah yaitu 26,55\% (T0M0). Hasil ini menunjukkan bahwa terdapat pengaruh antara perlakuan pemberian ekstrak daun kersen dan lama penyimpanan untuk meningkatkan kadar lemak kasar ampas kelapa. Uji wilayah berjarak Duncan terhadap lemak kasar ampas kelapa tersaji pada tabel 1 .
Ampas kelapa yang disimpan tanpa pemberian ekstrak mampu meningkatkan kadar lemak kasar, hal ini karena selama proses penyimpanan terdapat aktivitas bakteri yang menghasilkan asam lemak cukup tinggi sehingga kandungan lemak cenderung meningkat. Kurniati (2016) menyatakan bahwa semakin lama pakan disimpan kandungan lemak kasar semakin meningkat, hal ini karena terjadinya proses degradasi terhadap bahan organik yang dimanfaatkan oleh bakteri membentuk lemak. Arif (2018) menambahkan kadar lemak kasar mengalami peningkatan karena adanya aktivitas bakteri yang menghasilkan asam lemak cukup tinggi saat fermentasi. Penambahan ekstrak daun kersen juga mampu meningkatkan kadar lemak kasar, hal ini karena kandungan ekstrak daun kersen mampu menghambat reaksi oksidasi. Kandungan yang ada pada ekstrak daun kersen antara lain flavonoid yang berfungsi sebagai antioksidan. Hal ini didukung oleh pendapat Ayunda (2014) menyatakan bahwa flavonoid yang terkandung dalam suatu bahan berfungsi sebagai antioksidan alami yang dapat menghambat proses oksidasi. Mekanisme kerja antioksidan yaitu untuk menghambat oksidasi lemak. Reaksi oksidasi oleh radikal bebas dapat ditunda atau dihambat dengan adanya antioksidan. Tanpa antioksidan maka reaksi oksidasi lemak akan mengalami terminasi melalui reaksi antar radikal bebas (Tamu, 2017).

Hasil uji proksimat menunjukkan bahwa terdapat pengaruh nyata $(\mathrm{p}<0,05)$ pada perlakuan penambahan ekstrak daun kersen dan lama penyimpanan yang berbeda terhadap kadar serat kasar pada ampas kelapa. Kandungan serat kasar tertinggi yaitu 48,49\% (T0M0) dan terendah yaitu 46,86\% (T1M0). Hasil ini menunjukkan bahwa semakin lama masa simpan maka kadar serat kasar semakin turun, begitu juga dengan penambahan ekstrak daun kersen dapat menurunkan kadar serat kasar pada ampas kelapa. Uji wilayah berjarak Duncan 
terhadap kadar serat kasar pada ampas kelapa tersaji pada tabel 1.

Kadar serat kasar yang menurun pada ampas kelapa diduga karena adanya proses degradasi. Farizaldi (2016) menyatakan bahwa penurunan kadar serat kasar terjadi karena adanya proses degradasi substrat yang ada dalam ampas kelapa yaitu berupa selulosa dan hemiselulosa serta putusnya ikatan lignoselulosa. Degradasi serat kasar juga terjadi karena bakteri. Menurut Nurhajati dan Suprapto, (2013) perlakuan fermentasi dengan bakteri selulotik terbukti dapat menurunkan kandungan serat kasar pada ampas kelapa. Kadar serat kasar menurun seiring dengan lamanya waktu penyimpanan. Hal ini sesuai dengan Styawati et al. (2014) menyatakan bahwa semakin lama waktu fermentasi pada waktu tertentu, maka kesempatan mikroba untuk mendegradasi semakin tinggi.

Berdasarkan hasil uji proksimat, terdapat pengaruh nyata $(\mathrm{p}<0,05)$ pada perlakuan pemberian ekstrak daun kersen dan lama penyimpanan yang berbeda terhadap kadar protein kasar pada ampas kelapa. Kandungan protein kasar tertinggi yaitu 5,71\% (T0M4) dan terendah yaitu 4,81\% (T1M2). Hasil ini menunjukkan bahwa semakin lama disimpan maka kandungan protein kasar pada ampas kelapa akan semakin meningkat. Pemberian ekstrak daun kersen juga mampu meningkatkan kandungan protein kasar pada ampas kelapa. Uji wilayah berjarak Duncan terhadap kandungan protein kasar pada ampas kelapa tersaji pada tabel 1 .

Kandungan protein yang dihasilkan pada ampas kelapa mengalami peningkatan. Peningkatan kadar protein disebabkan karena adanya pertumbuhan mikroba selama proses penyimpanan. Setiawan (2017) meyatakan bahwa adanya aktifitas enzim yang dihasilkan oleh mikroba mampu meningkatkan kandungan protein. Menurut Hardianti et al. (2017) peningkatan kadar protein kasar selama masa penyimpanan diduga karena terjadi perombakan protein dari ampas kelapa menjadi asam amino oleh mikroba. Asam amino tersebut kemudian digunakan oleh mikroba untuk dapat memperbanyak diri, sehingga jumlah koloni mikroba dapat terhitung sebagai protein kasar. Penambahan ekstrak daun kersen juga mampu meningkatkan kadar protein dalam ampas kelapa, karena daun kersen merupakan tanaman yang mengandung protein cukup tinggi. Hal ini sesuai dengan pendapat Puspitaning (2012) menyatakan bahwa daun kersen merupakan tanaman yang memiliki kandungan protein yang lebih tinggi $(15,22 \%)$ dibanding dengan rumput lapang $(9,60 \%)$.

\section{Total Fungi}

Pengamatan total fungi dari ampas kelapa yang disimpan dan diberi ekstrak daun kersen dalam kemasan karung blacu dapat dilihat pada tabel 2. Berdasarkan analisis ragam menggunakan rancangan acak lengkap (RAL) pola faktorial menunjukkan bahwa interaksi antara perlakuan penambahan ekstrak daun kersen dan lama penyimpanan berpengaruh nyata $(\mathrm{P}<0,05)$ terhadap total fungi pada ampas kelapa. Nilai rata-rata hasil uji total fungi berkisar antara 5,52-6,21 Cfu/g. Angka tertinggi diperoleh pada perlakuan T0M0 $(6,62 \mathrm{Cfu} / \mathrm{g})$, dan angka terendah pada T1M0 (4,98 Cfu/g). Uji wilayah berjarak Duncan terhadap total fungi pada ampas kelapa tersaji pada tabel 2. Hasil ini menunjukkan bahwa ampas kelapa dengan penambahan ekstrak daun kersen terbukti dapat menurunkan jumlah fungi.

Penambahan ekstrak daun kersen diduga mengurangi adanya aktivitas mikroba pada ampas kelapa, sehingga pertumbuhan jamur dapat berkurang. Ekstrak daun kersen mengandung flavonoid yang berfungsi sebagai antimikroba. Hal ini sesuai dengan pendapat Prasetyanti et al. (2016) menyatakan bahwa kandungan flavonoid, tanin dan saponin yang ada dalam daun kersen digunakan sebagai antibakteri. 
Tabel 2. Rata-rata total fungi pada ampas kelapa yang diberi perlakuan selama penyimpanan.

\begin{tabular}{|c|c|c|c|c|}
\hline \multirow[b]{2}{*}{ Perlakuan } & \multicolumn{3}{|c|}{ Lama Penyimpanan } & \multirow[b]{2}{*}{ Rata-rata } \\
\hline & M0 & M2 & M4 & \\
\hline & \multicolumn{4}{|c|}{------------Cfu/g------------' } \\
\hline T0 & $6,62^{\mathrm{a}}$ & $6,15^{\mathrm{a}}$ & $5,86^{\mathrm{a}}$ & 6,21 \\
\hline $\mathrm{T} 1$ & $4,98^{\mathrm{b}}$ & $5,89^{\mathrm{b}}$ & $5,68^{\mathrm{a}}$ & 5,52 \\
\hline Rata-rata & 5,80 & 6,02 & 5,77 & \\
\hline
\end{tabular}

Flavonoid memiliki fungsi sebagai antibakteri yaitu menghambat sintesis asam nukleat, menghambat fungsi membrane sitoplasma dan menghambat metabolisme energi sehingga dinding bakteri yang terkena flavonoid akan kehilangan permeabilitas sel (Kurniawan et al., 2013). Menurut Khasanah et al. (2014) zat - zat aktif yang juga tergantung pada daun kersen seperti tanin dan saponin juga memiliki fungsi sebagai antibakteri.

\section{Total Bakteri}

Pengamatan total bakteri dari ampas kelapa yang disimpan dan diberi ekstrak daun kersen dalam kemasan karung blacu dapat dilihat pada tabel 3 .

Tabel 3. Rata-rata total bakteri pada ampas kelapa yang diberi perlakuan selama penyimpanan.

\begin{tabular}{|c|c|c|c|c|}
\hline \multirow[b]{2}{*}{ Perlakuan } & \multicolumn{3}{|c|}{ Lama Penyimpanan } & \multirow[b]{2}{*}{ Rata-rata } \\
\hline & M0 & M2 & M4 & \\
\hline & \multicolumn{4}{|c|}{------------Cfu/g------------ } \\
\hline T0 & $5,09^{b}$ & $5,91^{\mathrm{ab}}$ & $5,73^{\mathrm{a}}$ & 5,58 \\
\hline $\mathrm{T} 1$ & $4,29^{\mathrm{b}}$ & $6,22^{\mathrm{ab}}$ & $6,43^{\mathrm{a}}$ & 5,65 \\
\hline Rata-rata & 4,69 & 6,07 & 6,08 & \\
\hline
\end{tabular}

Keterangan : Superskrip yang berbeda pada baris dan kolom yang sama menunjukkan perbedaan yang sangat nyata $(\mathrm{p}<0,05)$

Berdasarkan hasil uji total bakteri, menunjukkan bahwa interaksi antara perlakuan penambahan ekstrak daun kersen dan lama penyimpanan tidak berpengaruh nyata $(\mathrm{P}>0,05)$ terhadap total bakteri. Angka tertinggi diperoleh pada perlakuan T1M4 $(6,43 \mathrm{Cfu} / \mathrm{g})$ dan angka terendah pada perlakuan T1M0 (4,29 Cfu/g). Uji wilayah berjarak Duncan terhadap total bakteri pada ampas kelapa tersaji pada tabel 3. Hasil ini menunjukkan bahwa lama penyimpanan ampas kelapa dan penambahan ekstrak daun kersen tidak mampu menghambat tumbuhnya bakteri.

Peningkatan jumlah bakteri pada ampas kelapa dapat disebabkan karena suhu dan kelembaban selama masa simpan. Hal ini sesuai dengan pendapat Kumalaningsih et al. (2014) menyatakan bahwa pertumbuhan bakteri dapat dipengaruhi oleh beberapa faktor antara lain temperatur, kelembaban, dan substansi penghambat. Solihin et al. (2015) menjelaskan bahwa semakin lama masa simpan maka kadar air akan semakin meningkat dan menunjang pertumbuhan mikroba, sehingga akan lebih mempercepat kerusakan pada bahan pakan ternak. Kadar uap air yang dihasilkan selama penyimpanan akan mudah mempengaruhi tumbuhnya bakteri.

Perlakuan penambahan ekstrak daun kersen tidak dapat menurunkan pertumbuhan total bakteri. Hal ini disebabkan oleh konsentrasi penambahan ekstrak daun kersen yang diberikan pada ampas kelapa masih kurang. Menurut Ratnasari (2017) semakin tinggi ekstrak daun kersen yang dicampurkan, maka akan semakin tinggi pula zona hambat bakteri yang tumbuh. Sulaiman et al. (2017) menyatakan bahwa konsentrasi ekstrak daun kersen yang memiliki daya hambat terbesar terhadap pertumbuhan bakteri adalah sebesar $75 \%$. Hal ini karena semakin tinggi konsentrasi ekstrak maka akan semakin banyak zat aktif didalam daun kersen yang berperan sebagai antibakteri yang mampu menghambat bakteri. 


\section{KESIMPULAN}

Ekstrak daun kersen yang ditambahkan pada ampas kelapa mampu mengurangi jumlah total fungi, namun tidak dapat mengurangi total bakteri. Pengaruh penambahan ekstrak daun kersen dan lama penyimpanan yang berbeda sama-sama mampu menurunkan kadar air, dan kadar serat kasar serta mampu meningkatkan kadar abu, kadar lemak kasar, dan kadar protein kasar pada ampas kelapa. Disarankan, dilakukan penelitian lebih lanjut terkait dengan penambahan ekstrak daun kersen terhadap lama penyimpanan, dosisnya, dan metode ekstraksi yang mudah diaplikasikan.

\section{DAFTAR PUSTAKA}

Arif, R. S. 2018. Pengaruh Lama Penyimpanan terhadap Kandungan Protein Kasar dan Lemak Kasar Pakan Komplit yang Diramu Secara As Fed. Fakultas Peternakan, Universitas Hasanuddin, Makassar. (Skripsi).

Ayunda, R. D. 2014. Aktivitas Antioksidan Ekstrak Etanol Daun Serai (Cymbopogon citratus) dan Potensinya sebagai Pencegah Oksidasi Lipid. Departemen Biokimia, Fakultas Matematika dan Ilmu Pengetahuan Alam. Institut Pertanian Bogor. (Skripsi)

Fardiaz, S. 1993. Analisis Mirobiologi Pangan. Raja Grafindo Persada, Jakarta.

Farizaldi. 2016. Evaluasi kandungan nutrisi ampas kelapa terfermentasi dengan ragi lokal dan lama fermentasi yang berbeda. J. Penelitian Universitas Jambi Seri Sains. 18 (1) : 49-55.

Hardianti, M., B. Sulistiyanto, S. Sumarsih 2017. Pengaruh penambahan bentonit pada proses pelleting limbah penetasan terhadap kandungan nutrisi produk pelet pasca-penyimpanan. Proseding Seminar Nasional Teknologi Peternakan dan Veteriner.

Hatma, A. T., B. I. M. Tampoebolon, B. W. H. E. Prasetiyono. 2018. Pengaruh perbedaan aras starter dan lama fermentasi terhadap kadar protein kasar, serat kasar, dan TDN (Total Digestible Nutrients) klobot jagung teramoniasi. Prosiding Seminar Nasional Kebangkitan Peternakan III. Semarang, 3 Mei 2018, Semarang.

Hidayati, S. G. 2011. Pengolahan ampas kelapa dengan mikroba local sebagai bahan pakan ternak ungas alernatif di Sumatera Barat. J. Embrio. 4 (1) : 2636.

Khasanah, I., Sarwiyono, dan P. Surjowardojo. 2014. Ekstrak etanol daun kersen (Muntingia calabura L.) sebagai antibakteri terhadap Streptococcus agalactiae penyebab mastitis subklinis pada sapi perah. Program Sarjana Produksi Ternak, Fakultas Peternakan, Universitas Brawijaya Malang. (Skripsi).

Kumalaningsih, S., Wignyanto, V. R. Permatasari, dan A. Triyono. 2014. Pengaruh jenis mikroorganisme dan $\mathrm{pH}$ terhadap kualiats minuman probiotik dari ampas tahu. Fakultas Teknologi Pertanian, Universitas Brawijaya. (Skripsi).

Kurniati. 2016. Kandungan Lemak Kasar, Bahan Organik, dan Bahan Ekstrak Tanpa Nitrogen Silase Pakan Lengkap Berbahan Utama Batang Pisang (Musa paradisiaca) dengan Lama Inkubasi yang Berbeda. Fakultas Peternakan, Universitas Hasanuddin, Makassar. (Skripsi).

Kurniawan, I., Sarwiyono dan P. Surjowardojo. 2013. Pengaruh teat dipping menggunakan dekok daun kersen (Muntingia calabura L.) 
terhadap tingkat kejadian mastitis. J. Ilmu-ilmu Peternakan. 23 (3) : 27 31.

Kurniawan, H., R. Utomo, dan L. M. Yusiati. 2016. Kualitas nutrisi ampas kelapa (Cocos nucifera L.) fermentasi menggunakan Aspergillus niger. Buletin Peternakan. 40 (1) : 26-33.

Malaka, R., Metusalach, E. Abustam. 2013. Pengaruh jenis mineral terhadap produksi eksoplisakarida dan karrakteristik pertumbuhan Lactobacillus bulgaricus strain Ropy dalam media susu. Seminar Nasional Teknologi Peternakan dan Veteriner.

Nurhajati, T. dan T. Suprapto. 2013. Penurunan serat kasar dan peningkatan protein kasar sabut kelapa (Cocos nucifera Linn) secara amofer dengan bakteri selulotik (Actinobacillus ML-08) dalam pemanfaatan limbah pasar sebagai sumber bahan pakan. J. Agroveteriner. 2 (1) : 1-11.

Prasetyanti, D. R., C. Budiarti, dan D. W. Harjanti. 2016. Efektifitas daun kersen (Muntinga calabura L.) dalam menurunkan jumlah bakteri dalam susu dan peradangan pada ambing sapi perah. J. Ilmu-ilmu Peternakan. 19 (1) : 10-16.

Pravitasari, G. A. 2017. Pengaruh Penambahan Fermentasi Ampas Kelapa (Cocos nucifera L.) oleh Ragi Tempe sebagai Campuran Pakan terhadap Bobot, Rasio Pakan, dan Income Over Feed Cost Ayam Kampung (Gallus gallus domesticus). Sarjana Pendidikan Biologi Fakultas Keguruan dan Ilmu Pendidikan Universitas Jember, Jember. (Skripsi).

Purwanti, M., P. Jamaluddin, Kadirman. 2017. Penguapan air dan penyusutan irisan ubi kayu selama proses pengeringan menggunakan mesin
Cabinet Dryer. J. Pendidikan Teknologi Pertanian. 3 (1) : 127-136.

Puspitaning, I. R. 2012. Populasi Protozoa dan Karakteristik Fermentasi Rumen dengan Pemberian Daun Kersen (Muntingia calabura) In Vitro. Departemen Ilmu Nutrisi dan Teknologi Pakan, Fakultas Peternakan, Institut Pertanian Bogor. (Skripsi).

Puspitasari, N. dan M. Sidik. 2009. Pengaruh Jenis Vitamin B dan Sumber Nitrogen dalam Peningkatan Kandungan Protein Kulit Ubi Kayu Melalui Proses Fermentasi. Seminar Tugas Akhir, Program Studi Teknik Kimia, Universitas Diponegoro, Semarang.

Putri, M. F. 2010. Tepung ampas kelapa pada umur panen 11-12 bulan sebagai bahan pangan sumber kesehatan. Jurusan Teknologi Jasa dan Produksi, Universitas Negeri Semarang. Semarang. J. Kompetensi Teknik. 1 (2) : 97 - 105.

Ratnasari, M. 2017. Uji Aktivitas Antibakteri Ekstrak Daun Kersen (Muntingia calabura L.) Dalam Bentuk Sediaan Gel terhadap Staphylococcus aureus dan Escherichia coli. Program Studi Biologi, Fakultas Teknobiologi, Universitas Atmajaya, Yogyakarta. (Skripsi).

Retnani, Y., D. Kurniawan, S.Yusawisana, L. Herawati. 2010. Kerusakan lemak ransum ayam broiler yang menggunakan Cruide Palm Oil (CPO) dengan penambahan antioksidan alami bawang putih (Alium sativum) dan jintan (Cuminum cyminum Linn.) selama penyimpanan. J. Ilmu dan Teknologi Peternakan. 1 (1) : 1-11.

Sari, I., T. Miranda, dan Sadli. 2016. The cytotoxic activity of N-hexane extract of kersen (muntingia calabura Linn.) 
leaves using the brine shrimp lethality test (BSLT) method. J. Natural. 16 (2) : 37-44.

Setiawan, B. 2017. Kandungan Protein Kasar dan Serat Kasar Dedak Padi yang Difermentasi dengan Mikroorganisme Lokal. Fakultas Peternakan, Universitas Hasanuddin, Makassar. (Skripsi).

Solihin, Muhtarudin, R. Sutrisna. 2015. Pengaruh lama penyimpanan terhadap kadar air kualitas fisik dan sebaran jamur wafer limbah sayuran dan umbi-umbian. J. Ilmiah Peternakan Terpadu. 3 (2) : 48-54.

Styawati, N. E., Muhtarudin, Liman. 2014. Pengaruh lama fermentasi Trametes sp. terhadap kadar bahan kering, kadar abu, dan kadar serat kasar daun nenas varietas Smooth cayene. J. Ilmiah Peternakan Terpadu. 2 (1) : 19-24.

Sulaiman, A. Y., P. Astuti., A. D. P. Shita. 2017. Uji antibakteri ekstrak daun kersen (Muntingia calabura L.) terhadap koloni Streptococcus viridians. J. Indonesian for Health Sciences. 1 (2) : 1-6.

Tamu, F. 2017. Formulasi dan Uji Efektivitas Antioksidan Krim Ekstrak Etanol Daun Kersen (Muntingia calabura L). Fakultas Kedokteran dan Ilmu Kesehatan, Universitas Islam Negeri Alauddin Makassar. (Skripsi).

Widaningrum., Miskiyah, A. S. Somantri. 2010. Perubahan sifat fisiko-kimia biji jagung (Zea mays L.) pada penyimpanan dengan perlakuan karbondioksida $\left(\mathrm{CO}_{2}\right)$. J. Agritech. 30 (1) : 36-45.

Wulandari, S., F. Fathul, Liman. 2015. Pengaruh berbagai komposisi limbah pertanian terhadap kadar air, abu, dan serat kasar pada wafer. J. Ilmiah Peternakan Terpadu. 3 (3) : 104-109.

Yamin, M. 2008. Pemanfaatan ampas kelapa dan ampas kelapa fermentasi dalam ransum terhadap efisiensi ransum dan income over feed cost ayam pedaging. J. Agroland. 15 (2) : 135-139 